\title{
Pilot and feasibility trials in traditional Chinese medicine: a literature review of current practice
}

\author{
Guowei $\mathrm{Li}^{12^{* \dagger}}$, Darong $\mathrm{Wu}^{3,4 \dagger}$, Xuejiao Chen ${ }^{1+}$, Jie Zeng ${ }^{1}$, Ziyi Li ${ }^{1}$ and Lehana Thabane ${ }^{2}$
}

\begin{abstract}
Background: The guidelines for pilot and feasibility studies were published in 2016. Little is known about the guideline adherence of TCM (traditional Chinese medicine) pilot trials or whether the guidelines can significantly enhance the quality of implementation and reporting of TCM pilot trials. We aimed to investigate the guideline adherence, assess the impact of guidelines on TCM pilot trials, and discuss potential challenges specific to TCM pilot trials, by conducting a literature review.
\end{abstract}

Methods: We systematically searched MEDLINE, EMBASE, and CNKI to retrieve TCM pilot trials. We randomly chose 50 pilot trials from the eligible studies for analyses. The CONSORT extension to pilot and feasibility studies was used as a framework to assess the methodology and reporting quality of the studies.

Results: The included studies had a guideline adherence level ranging from 4 to $96 \%$, where the lowest adherence was found in the item $6 c$ (prespecified criteria used to judge progression to future definitive trial). The guidance published in 2016 seemed to exert minimal effect on guideline adherence in TCM pilot trials. The unidentified issues related to TCM pilot trials from the guidelines included blinding, lack of standard formula of interventions, difficulty in comparison for effect assessment of interventions, and difficulty in bias control.

Conclusions: The current practice in TCM pilot trials required substantial improvement in the literature. Further endeavors are needed for training and dissemination of guideline adherence, and development of more detailed methodology in the field of TCM pilot trials.

Keywords: Traditional Chinese medicine, Pilot trial, Feasibility, Guideline adherence

\section{Introduction}

Pilot and feasibility trials have been published with a growing number. Pilot trials are significantly important for the design of a future main trial (or definitive trial) by providing evidence of feasibility issues and avoiding

\footnotetext{
* Correspondence: lig28@mcmaster.ca

${ }^{\dagger}$ Guowei Li, Darong Wu and Xuejiao Chen contributed equally to this work. ${ }^{1}$ Center for Clinical Epidemiology and Methodology (CCEM), Guangdong Second Provincial General Hospital, 466 Newport Middle Road, Haizhu District, Guangzhou 510317, Guangdong Province, China

${ }^{2}$ Department of Health research methods, Evidence, and Impact (HEl), McMaster University, 1280 Main St West, Hamilton, ON L8S 4 L8, Canada Full list of author information is available at the end of the article
}

wasted recourses [1]. In 2016, Eldridge et al. published two critical publications aiming to reduce the misunderstanding and improve the reporting quality of pilot trials: the first providing a conceptual framework to define a pilot trial [2], and the second developing a CONSORT (Consolidated Standards of Reporting Trials) extension for pilot trials with a 26-item checklist included [3]. While the two publications may help with the design, implementation, reporting, and dissemination of pilot trials, it remains largely unknown about their impact on the pilot trials published in the literature. Confusions remained in the pilot trials including their definitions

C C The Author(s). 2020 Open Access This article is licensed under a Creative Commons Attribution 4.0 International License, which permits use, sharing, adaptation, distribution and reproduction in any medium or format, as long as you give appropriate credit to the original author(s) and the source, provide a link to the Creative Commons licence, and indicate if changes were made. The images or other third party material in this article are included in the article's Creative Commons licence, unless indicated otherwise in a credit line to the material. If material is not included in the article's Creative Commons licence and your intended use is not permitted by statutory regulation or exceeds the permitted use, you will need to obtain permission directly from the copyright holder. To view a copy of this licence, visit http://creativecommons.org/licenses/by/4.0/ The Creative Commons Public Domain Dedication waiver (http://creativecommons.org/publicdomain/zero/1.0/) applies to the data made available in this article, unless otherwise stated in a credit line to the data. 
and terms, purpose, sample size determination, and criteria for progression or cessation, to mention a few [4-6].

Traditional Chinese medicine (TCM) is a hot topic in the health research community, especially given its alternative and integrated effect as a palliative treatment option [7]. Notably, some uncertainties and challenges exist in clinical trials for TCM that mainly include the difficulty in standardized procedures, potential heterogeneity in interventions and operators, control selection, and outcome assessment. Pilot trials for TCM offer a platform to identify and address these issues before a main trial. However, current evidence about the conduct and reporting of pilot trials for TCM is limited and sparse. Furthermore, little is known about whether the CONSORT extension for pilot trials can significantly enhance the quality of implementation and reporting of TCM pilot trials. Likewise, further evidence is needed to reveal the unidentified issues specific to TCM pilot trials from the guidelines [3]. Therefore, in this study, we conducted a literature review to investigate the guideline adherence of pilot trials for TCM, aiming to appraise the issues related to methodology and reporting. We also aimed to assess the impact of the CONSORT extension for pilot trials, and discuss any potential challenges specific to TCM pilot trials.

\section{Methods}

\section{Search strategy and study selection}

We systematically searched MEDLINE, EMBASE, and CNKI to retrieve TCM pilot trials. Descriptors including synonyms for traditional Chinese medicine or herbal medicine or folk medicine, and pilot trials or feasibility studies, were used in combination for the literature search (Supplemental Table 1 presents the search terms used). Studies were eligible for inclusion if they explicitly identified their TCM research as a randomized pilot or feasibility trial in the titles, abstracts, or introductions. Studies were excluded if they were not identified as a randomized pilot or feasibility trial, or they were not related to TCM, or they did not have information for methodological and reporting appraisal. Two reviewers (GL and XC) independently screened the records and determined study eligibility.

\section{Data extraction}

Data extraction was completed by two independent reviewers (GL and $\mathrm{XC}$ ). We categorized the included TCM pilot trials into two groups: (1) pilot trials that had at least one objective or assessment of feasibility and were conducted in preparation for a future definitive trial (FDT) and (2) trials that did not have feasibility objectives or assessment, termed as non-feasibility trials (NFT). This methodology was similar to Horne's approach [8]. We assessed the guideline adherence about Title and Abstract (1a and 1b listed in the checklist), Introduction ( $2 \mathrm{a}$ and $2 \mathrm{~b}$ ), Methods (3a, 4c, 6a, 6c, 7a, and 12a), Results (13a), and Discussion (20, 21, and 22a) [3], separated by the two groups (FDT and NFT).

To document the methodological issues specific to TCM pilot trials, we also extracted the relevant data throughout the text from the included studies, especially in their Discussion sections.

\section{Statistical analyses}

We expected that the proportion of FDT in our included studies would be approximately $15 \%$. Therefore, we randomly chose 50 pilot trials from the 285 eligible studies for analyses (Fig. 1 shows the process of identifying eligible studies). To assess the impact of CONSORT extension for pilot trials on reporting, we selected the 50 studies that were published in either before or after the year 2016; i.e., no studies published in 2016 were identified for our analyses.

Guideline adherence was presented using counts and percentages. We performed a chi-square test to compare the guideline adherence levels between the two groups (FDT and NFT). To evaluate the impact of the CONSORT extension for pilot trials, we compared the guideline adherence of the included pilot trials published before and after 2016. When there was a cell with expected frequency $<5$ in the contingency table, we used Fisher's exact test to compare the guideline adherence levels between the groups. All analyses were conducted using the STATA version 13 (Stata Corp., College Station, TX, USA).

\section{Results}

As shown in Fig. 1, we identified 285 eligible TCM pilot trials, among which 50 were randomly selected for analyses [9-58]. The selected 50 trials were published between year 1998 and 2019, and had a sample size ranging from 7 to 160 (Table 1). The TCM assessed in the trials included herbs, acupuncture, Chinese patent medicine, Qigong, massage, and others. There were 12 trials categorized as FDT (24\%) and 38 as NFT (76\%). Thirty-eight trials $(76 \%)$ were published before year 2016, and 12 trials (24\%) after 2016.

Table 2 presents the detailed guideline adherence levels of the selected trials. The adherence ranged from 4 to $96 \%$, with the lowest adherence found in 6c (prespecified criteria used to judge progression to future definitive trial) and highest in 12a (qualitative or quantitative methods used to address objectives). The checklist items $2 \mathrm{~b}$ (specific objectives or research questions), 7a (rationale for sample size), and 21 (generalizability of methods and findings) also had low guideline adherence levels (18\%, $8 \%$, and $18 \%$ respectively). Table 2 also shows 


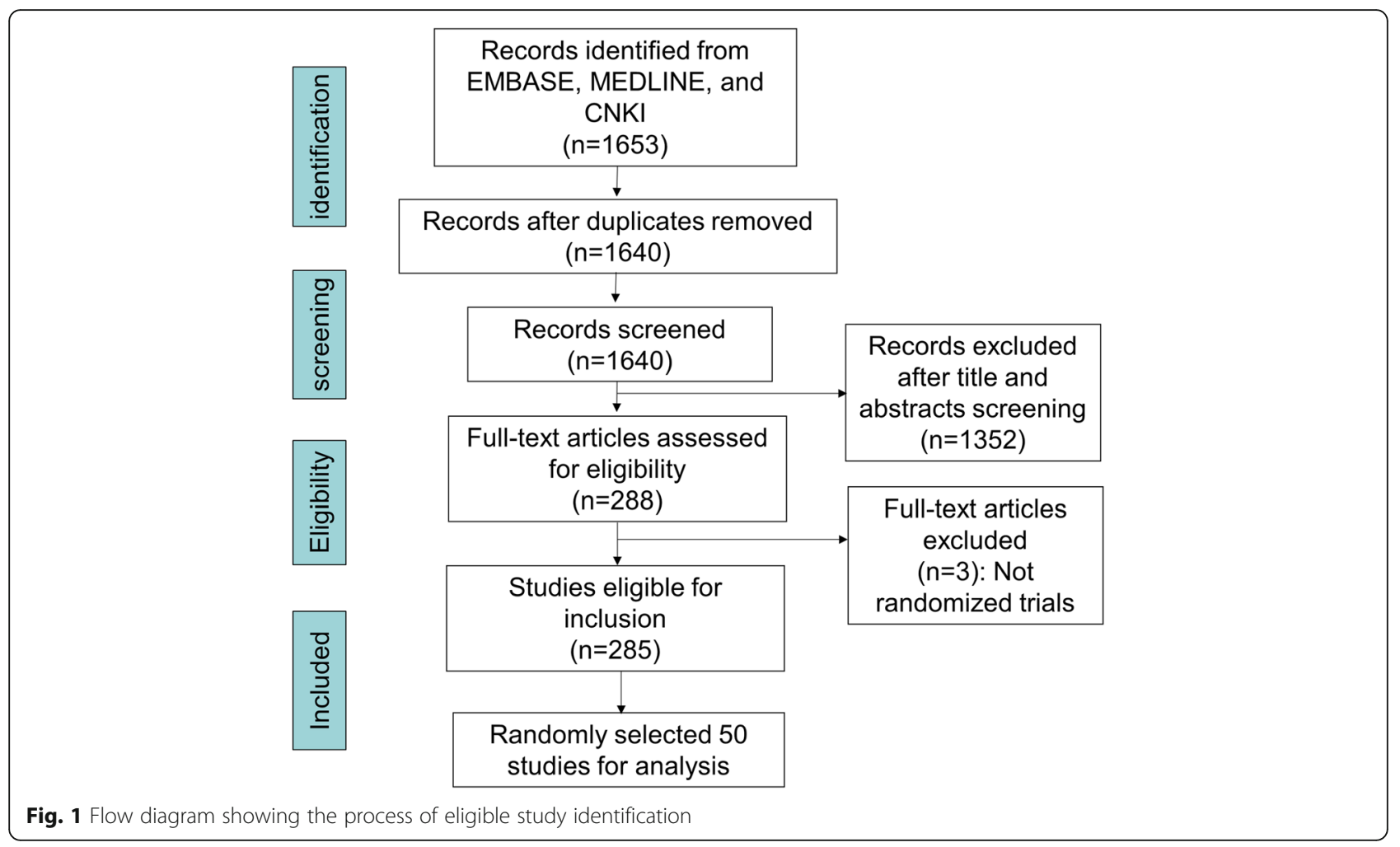

comparisons between FDT and NFT, and between studies published before and after year 2016. Compared with the NFT, the FDT had a significantly higher guideline adherence in the item $7 \mathrm{a}$ (rationale for sample size; $25 \%$ vs $3 \%$ ) and 20 (discussion of study limitation, bias and uncertainty; $58 \%$ vs $34 \%$ ). Guideline adherence level was only found significantly higher in the item 12a (qualitative or quantitative methods used to address objectives) in trials published after year 2016, when compared with studies published before 2016 (100\% vs 55\%).

The methodological issues specific to TCM pilot trials from the guidelines are shown in Table 3 . There were 3 trials raising the issue of blinding in TCM pilot trials, mainly due to the acupuncture, administration forms, smells, and other reasons [12, 27, 51]. Other issues included lack of standard formula of interventions, difficulty in comparison for effect assessment of interventions, and difficulty in bias control $[12,27,47,58]$ (Table 3). For instance, in a pilot trial conducted by Choi et al., they reported that it was extremely difficult to evaluate the intervention effect because no standard treatment for atopic dermatitis could be used for comparison based on the current evidence-based TCM [58].

\section{Discussion}

In this study, we performed a review to assess the guideline adherence of TCM pilot trials. The guideline adherence varied crossing the checklist items, where some items required significant improvement. The guidance papers published in 2016 seemed to exert minimal effect on guideline adherence in TCM pilot trials. We also identified several issues specific to TCM pilot trials in this review including blinding, standards for intervention and comparisons, effect assessment, and bias reduction.

Interestingly, there were only $24 \% \mathrm{TCM}$ pilot trials that had an objective of feasibility and were performed in preparation for future definitive trials (FDT). This indicated the inappropriate use of the term pilot in many small trials that aimed to test the hypotheses of efficacy or safety with an insufficient sample size albeit being underpowered to do so $[8,59,60]$. It also corresponded to the item $2 \mathrm{~b}$ (specific objectives or research questions), where surprisingly only 3 (25\%) in the FDT group clearly stated their objectives related to feasibility. Furthermore, there were only two items ( $7 \mathrm{a}$ and 20 ) found with significant improved guideline adherence in FDT compared with NFT, implying that more endeavors were required even in those pilot trials with specified feasibility objective(s). Therefore, all these findings suggested further dissemination of the guideline to help clarify the definition of feasibility and pilot trials [2] and to enhance the guideline adherence [3].

Likewise, our study indicated that the impact of CONSORT extension for pilot trials warranted more efforts in TCM pilot trials because the improvement was only found in one item (12a) after the guidelines were published 
Table 1 Characteristics of the 50 included studies

\begin{tabular}{|c|c|c|c|c|c|c|}
\hline $\begin{array}{l}\text { First study } \\
\text { author }\end{array}$ & $\begin{array}{l}\text { Publication } \\
\text { year }\end{array}$ & Journal & Country & Type of TCM & $\begin{array}{l}\text { Number of participants } \\
\text { randomized }\end{array}$ & $\begin{array}{l}\text { Type of pilot } \\
\text { trial }\end{array}$ \\
\hline Agarwal & 2014 & $\begin{array}{l}\text { Asian Journal of Pharmaceutical and } \\
\text { Clinical Research }\end{array}$ & India & Herb & 62 & NFT \\
\hline Ahn & 2007 & Acupuncture in Medicine & USA & Acupuncture & 32 & FDT \\
\hline Avis & 2008 & $\begin{array}{l}\text { The Journal of The North American } \\
\text { Menopause Society }\end{array}$ & USA & Acupuncture & 104 & NFT \\
\hline Chen & 2003 & Maturitas & China & Herb & 44 & FDT \\
\hline Choi & 2012 & $\begin{array}{l}\text { The Journal of Alternative and } \\
\text { Complementary Medicine }\end{array}$ & Korea & Herb & 40 & NFT \\
\hline Chung & 2012 & Journal of Affective Disorders & China & Acupuncture & 50 & FDT \\
\hline Gong & 2019 & $\begin{array}{l}\text { Evidence-Based Complementary and } \\
\text { Alternative Medicine }\end{array}$ & China & Herb & 63 & NFT \\
\hline Hsu & 2008 & Advance Access Publication & China & Herb & 24 & NFT \\
\hline Huang & 2019 & Plos One & China & Herb & 60 & FDT \\
\hline Iwasaki & 2007 & Journal of the American Geriatrics Society & Japan & Herb & 48 & NFT \\
\hline Jones & 2001 & $\begin{array}{l}\text { BMC Complementary and Alternative } \\
\text { Medicine }\end{array}$ & China & Qigong & 117 & NFT \\
\hline Kainuma & 2004 & Human Psychopharmacology & Japan & Herb & 33 & NFT \\
\hline Kalman & 2007 & Nutrition Journal & USA & $\begin{array}{l}\text { Chinese patent } \\
\text { medicine }\end{array}$ & 60 & NFT \\
\hline Kampman & 2003 & Addictive Behaviors & USA & Herb & 14 & NFT \\
\hline Kang & 1999 & Hong Kong Medical Journal & China & $\begin{array}{l}\text { Chinese patent } \\
\text { medicine }\end{array}$ & 120 & NFT \\
\hline Kong & 2009 & Cerebrovasc Diseases & Singapore & Herb & 60 & FDT \\
\hline Kuo & 2012 & $\begin{array}{l}\text { Evidence-Based Complementary and } \\
\text { Alternative Medicine }\end{array}$ & China & Herb & 28 & NFT \\
\hline Kuratsune & 2010 & Phytomedicine & Japan & Herb & 12 & NFT \\
\hline Ladas & 2010 & Cancer & USA & Herb & 106 & FDT \\
\hline Lee & 2010 & Complementary Therapies in Medicine & China & Herb & 28 & NFT \\
\hline Lee & 2011 & Planta Medica & Korea & $\begin{array}{l}\text { Chinese patent } \\
\text { medicine }\end{array}$ & 40 & NFT \\
\hline Li & 2009 & Complementary Therapies in Medicine & China & Herb & 24 & NFT \\
\hline Li & 2015 & HIV Clinical Trials & China & Herb & 140 & NFT \\
\hline Liew & 2015 & Asia Pacific allergy & Singapore & $\begin{array}{l}\text { Chinese patent } \\
\text { medicine }\end{array}$ & 44 & FDT \\
\hline Liu & 2018 & $\begin{array}{l}\text { Evidence-Based Complementary and } \\
\text { Alternative Medicine }\end{array}$ & China & $\begin{array}{l}\text { Chinese patent } \\
\text { medicine }\end{array}$ & 20 & NFT \\
\hline Luo & 2018 & European Journal of Integrative Medicine & China & Acupuncture & 20 & FDT \\
\hline Noorbala & 2005 & Journal of Ethnopharmacology & Iran & Herb & 88 & NFT \\
\hline Otto & 1998 & American Academy of Addiction Psychiatry & USA & Acupuncture & 19 & NFT \\
\hline Pan & 2018 & Chinese Journal of Integrative Medicine & China & Other & 60 & NFT \\
\hline Reshef & 2013 & Sleep Disorders & Israel & Acupuncture & 27 & NFT \\
\hline Ritenbaugh & 2008 & $\begin{array}{l}\text { The Journal of Alternative and } \\
\text { Complementary Medicine }\end{array}$ & USA & Other & 18 & FDT \\
\hline Scheid & 2015 & Maturitas & $\begin{array}{l}\text { United } \\
\text { Kingdom }\end{array}$ & $\begin{array}{l}\text { Herb and/or } \\
\text { acupuncture }\end{array}$ & 42 & FDT \\
\hline Shelmadine & 2017 & $\begin{array}{l}\text { The Journal of Alternative and } \\
\text { Complementary Medicine }\end{array}$ & USA & $\begin{array}{l}\text { Chinese patent } \\
\text { medicine }\end{array}$ & 56 & NFT \\
\hline Singh & 2010 & Indian Journal of Medical Sciences & India & Herb & 7 & NFT \\
\hline
\end{tabular}


Table 1 Characteristics of the 50 included studies (Continued)

\begin{tabular}{|c|c|c|c|c|c|c|}
\hline $\begin{array}{l}\text { First study } \\
\text { author }\end{array}$ & $\begin{array}{l}\text { Publication } \\
\text { year }\end{array}$ & Journal & Country & Type of TCM & $\begin{array}{l}\text { Number of participants } \\
\text { randomized }\end{array}$ & $\begin{array}{l}\text { Type of pilot } \\
\text { trial }\end{array}$ \\
\hline Sitzia & 2019 & Clinical Trial & Italy & Other & 56 & NFT \\
\hline Sordi & 2019 & Journal of Natural Remedies & Brazil & Herb & 70 & NFT \\
\hline Spasov & 2000 & Phytomedicine & Russia & herb & 128 & NFT \\
\hline Stockert & 2007 & Pediatr Allergy Immunol & Austria & Acupuncture & 12 & NFT \\
\hline Tao & 2013 & $\begin{array}{l}\text { Evidence-Based Complementary and } \\
\text { Alternative Medicine }\end{array}$ & France & Other & 40 & NFT \\
\hline Tsai & 2018 & Complementary Therapies in Medicine & China & Herb & 160 & NFT \\
\hline Wang & 2014 & Prev Chronic Dis & USA & $\begin{array}{l}\text { Herb and/or } \\
\text { acupuncture }\end{array}$ & 70 & FDT \\
\hline Wei & 2015 & $\begin{array}{l}\text { International Journal of Clinical and } \\
\text { Experimental Medicine }\end{array}$ & China & $\begin{array}{l}\text { Chinese patent } \\
\text { medicine }\end{array}$ & 18 & NFT \\
\hline Wong & 2006 & Journal of Child Neurology & China & Acupuncture & 120 & NFT \\
\hline Wu & 2014 & Journal of Clinical Medical & China & $\begin{array}{l}\text { Acupuncture and } \\
\text { massage }\end{array}$ & 36 & NFT \\
\hline Wu & 2015 & Neuropsychiatric Disease and Treatment & China & Herb & 46 & NFT \\
\hline $\mathrm{Xu}$ & 2009 & Phytotherapy Research & China & $\begin{array}{l}\text { Chinese patent } \\
\text { medicine }\end{array}$ & 30 & NFT \\
\hline Yu & 2018 & $\begin{array}{l}\text { Journal of Acupuncture and Meridian } \\
\text { Studies }\end{array}$ & Canada & Acupuncture & 60 & NFT \\
\hline Zhang & 2015 & Journal of Alzheimer's Disease & China & $\begin{array}{l}\text { Chinese patent } \\
\text { medicine }\end{array}$ & 12 & NFT \\
\hline Zou & 2017 & Journal of Nutrition Health \& Aging & Canada & Other & 21 & FDT \\
\hline Zou & 2017 & Inquiry & Canada & Other & 36 & NFT \\
\hline
\end{tabular}

FDT trials in preparation for a future definitive trial, NFT non-feasibility trials

(Table 2). The minimal effect of the guidance papers may be because either the guidelines did not reach the relevant research parties, or that the guidelines were largely ignored by the research parties [8]. In any case, our review reveals the urgent need for both training and dissemination of research methodology and guideline adherence in TCM pilot trials.

Besides the common practice of inappropriate hypothesis testing and insufficient power for conclusion in pilot trials $[59,61]$, our study also identified some issues specific to TCM pilot trials including blinding, standards for intervention and comparisons, and bias reduction (Table 3). This entails more guidance on methodology and reporting specific to TCM pilot trials because the existing guidelines including CONSORT extensions to acupuncture [62], herbal interventions [63], and pilot and feasibility studies [3] could not fully cover these issues in TCM pilot trials. The progression criteria (guideline adherence level, $4 \%$ ), sample size rationale (18\%), and generalizability of methods and findings (18\%) were also notable issues found in the TCM pilot trials (Table 2 ). This may be, at least in part, due to insufficient details on explanation and elaboration from the guideline. For example, even though the CONSORT extension recommended that authors should justify the number of participants in pilot trials [3], no sufficient details on how to exactly provide sample size rationale could be found in the guideline. Likewise, how to specify the progression criteria to determine whether the pilot trial can progress to future main trial, and whether the methods and findings can be generalizable to main trial and other pilot studies, required further detailed investigation and guidance in TCM pilot trials. The TCM field is substantially different from modern medicine, especially in their intervention, control, and outcome assessment. For example, our review found that the issues specific to TCM pilot trials including blinding, standards for intervention and comparisons, effect assessment, and bias reduction, were not discussed in the CONSORT extension (Table 3). Thus, our findings call for the need for further methodology and guidance in the research area of pilot and feasibility studies to address the methodological issues and the other notable issues specific to TCM pilot trials.

Our study was the first to explore the current practice of methodology and reporting in TCM pilot trials. We completed the data acquisition and analyses by two reviewers independently, thereby enhancing the accuracy of study findings [64]. There are also some limitations to our study. Due to the small numbers of the included FDT $(n=12)$ and studies published after year $2016(n=$ 
Table 2 Details for guideline adherence of the included studies

\begin{tabular}{|c|c|c|c|c|c|c|}
\hline \multirow{4}{*}{$\begin{array}{l}\text { Number } \\
\text { of item }\end{array}$} & \multirow[t]{4}{*}{ Checklist item } & \multicolumn{5}{|c|}{ Guideline adherence } \\
\hline & & \multirow{3}{*}{$\begin{array}{l}\text { Overall } \\
\text { studies } \\
(n= \\
50)\end{array}$} & \multicolumn{4}{|c|}{ Subgroups ${ }^{\#}$} \\
\hline & & & \multicolumn{2}{|c|}{$\begin{array}{l}\text { By type of pilot } \\
\text { trial }\end{array}$} & \multicolumn{2}{|c|}{ By year of publication } \\
\hline & & & $\begin{array}{l}\text { FDT }(n \\
=12)\end{array}$ & $\begin{array}{l}\text { NFT }(n= \\
38)\end{array}$ & $\begin{array}{l}\text { Studies published } \\
\text { before } 2016(n= \\
\text { 38) }\end{array}$ & $\begin{array}{l}\text { Studies } \\
\text { published after } \\
2016(n=12)\end{array}$ \\
\hline \multicolumn{7}{|c|}{ Title and abstract } \\
\hline $1 \mathrm{a}$ & Identification as a pilot or feasibility randomized trial in the title & $\begin{array}{l}47 \\
(94.0)\end{array}$ & $\begin{array}{l}11 \\
(91.7)\end{array}$ & $36(94.7)$ & $36(94.7)$ & $11(91.7)$ \\
\hline $1 b$ & $\begin{array}{l}\text { Structured summary of pilot trial design, methods, results, and } \\
\text { conclusions (for specific guidance see CONSORT abstract extension } \\
\text { for pilot trials) }\end{array}$ & $\begin{array}{l}37 \\
(74.0)\end{array}$ & $9(75.0)$ & $28(73.7)$ & $27(71.1)$ & $10(83.3)$ \\
\hline \multicolumn{7}{|c|}{ Introduction } \\
\hline $2 a$ & $\begin{array}{l}\text { Scientific background and explanation of rationale for future } \\
\text { definitive trial, and reasons for randomized pilot trial }\end{array}$ & $\begin{array}{l}11 \\
(22.0)\end{array}$ & $3(25.0)$ & $8(21.1)$ & $8(21.1)$ & $3(25.0)$ \\
\hline $2 b$ & Specific objectives or research questions for pilot trial & $9(18.0)$ & $3(25.0)$ & $6(18.4)$ & $8(15.8)$ & $1(8.3)$ \\
\hline \multicolumn{7}{|l|}{ Methods } \\
\hline $3 a$ & $\begin{array}{l}\text { Description of pilot trial design (such as parallel, factorial) including } \\
\text { allocation ratio }\end{array}$ & $\begin{array}{l}35 \\
(70.0)\end{array}$ & $8(66.7)$ & $27(71.1)$ & $26(68.4)$ & $9(75.0)$ \\
\hline $4 c$ & How participants were identified and consented & $\begin{array}{l}39 \\
(78.0)\end{array}$ & $9(75.0)$ & $30(79.0)$ & $29(76.3)$ & $10(83.3)$ \\
\hline 5 & $\begin{array}{l}\text { The interventions for each group with sufficient details to allow } \\
\text { replication, including how and when they were actually } \\
\text { administered }\end{array}$ & $\begin{array}{l}44 \\
(88.0)\end{array}$ & $\begin{array}{l}10 \\
(83.3)\end{array}$ & $34(89.5)$ & $34(89.5)$ & $10(83.3)$ \\
\hline $6 a$ & $\begin{array}{l}\text { Completely defined prespecified assessments or measurements to } \\
\text { address each pilot trial objective specified in } 2 \mathrm{~b} \text {, including how and } \\
\text { when they were assessed }\end{array}$ & $\begin{array}{l}44 \\
(88.0)\end{array}$ & $\begin{array}{l}10 \\
(83.3)\end{array}$ & $34(89.5)$ & $34(89.5)$ & $10(83.3)$ \\
\hline $6 c$ & $\begin{array}{l}\text { If applicable, prespecified criteria used to judge whether, or how, to } \\
\text { proceed with future definitive trial }\end{array}$ & $2(4.0)$ & $1(8.3)$ & $1(2.6)$ & $1(2.6)$ & $1(8.3)$ \\
\hline $7 a$ & Rationale for numbers in the pilot trial & $4(8.0)$ & $3(25.0)^{*}$ & $1(2.6)^{*}$ & $3(7.9)$ & $1(8.3)$ \\
\hline $12 \mathrm{a}$ & $\begin{array}{l}\text { Methods used to address each pilot trial objective whether } \\
\text { qualitative or quantitative }\end{array}$ & $\begin{array}{l}48 \\
(96.0)\end{array}$ & $\begin{array}{l}11 \\
(91.7)\end{array}$ & $37(97.3)$ & $21(55.3)^{*}$ & $12(100.0)^{*}$ \\
\hline \multicolumn{7}{|l|}{ Results } \\
\hline $13 a$ & $\begin{array}{l}\text { For each group, the numbers of participants who were approached } \\
\text { and/or assessed for eligibility, randomly assigned, received intended } \\
\text { treatment, and were assessed for each objective }\end{array}$ & $\begin{array}{l}34 \\
(68.0)\end{array}$ & $\begin{array}{l}10 \\
(83.3)\end{array}$ & $24(63.2)$ & $26(68.4)$ & $8(66.7)$ \\
\hline \multicolumn{7}{|c|}{ Discussion } \\
\hline 20 & $\begin{array}{l}\text { Pilot trial limitations, addressing sources of potential bias, and } \\
\text { remaining uncertainty about feasibility }\end{array}$ & $\begin{array}{l}33 \\
(66.0)\end{array}$ & $7(58.3)^{*}$ & $13(34.2)^{*}$ & $27(71.1)$ & $6(50.0)$ \\
\hline 21 & $\begin{array}{l}\text { Generalizability (applicability) of pilot trial methods and findings to } \\
\text { future definitive trial and other studies }\end{array}$ & $9(18.0)$ & $3(25.0)$ & $6(15.8)$ & $7(18.4)$ & $2(16.7)$ \\
\hline $22 a$ & $\begin{array}{l}\text { Implications for progression from pilot to future definitive trial, } \\
\text { including any proposed amendments }\end{array}$ & $\begin{array}{l}31 \\
(62.0)\end{array}$ & $6(50.0)$ & $25(65.8)$ & $24(63.2)$ & $7(58.3)$ \\
\hline
\end{tabular}

"two subgroup analyses conducted by study type (FDT vs NFT) and publication year (before 2016 vs after 2016)

${ }^{*} p$ value $<0.05$ for difference test

12), we only performed raw comparisons without adjustments, which may yield biased findings in univariate analyses. We could not further extract potential solutions from the included TCM studies, indicating the important gap in methodological guidance in TCM pilot trials. Furthermore, only studies in Chinese and English were screened and selected, which may therefore introduce selection bias due to lack of studies in other languages such as Japanese and Korean. Moreover, the impact of time lag between the publication of a new guideline and the adoption and implementation of it could not be fully assessed, which may therefore weaken the findings of our study.

To conclude, the current practice in TCM pilot trials required substantial improvement in the literature. The guideline seemed to have only minimal effect on the 
Table 3 Details of identified issues specific to TCM pilot trials

\begin{tabular}{|c|c|c|}
\hline $\begin{array}{l}\text { Issues specific to TCM pilot } \\
\text { trials }\end{array}$ & Authors' statements & Reference \\
\hline Blinding; intervention & $\begin{array}{l}\text { "in this study JWSYS [Jia-Wey Shiau-Yau San] was given in powder form and Premelle in tablet form. The } \\
\text { question arises as to whether the women receiving JWSYS were aware that they were taking an estab- } \\
\text { lished traditional Chinese herbal remedy. Since the trial was not a blind one and the improvement in the } \\
\text { symptoms of these women could be due to an expectancy/placebo effect, given the cultural milieu" }\end{array}$ & Chen [12] \\
\hline $\begin{array}{l}\text { Randomization and blinding; } \\
\text { intervention }\end{array}$ & $\begin{array}{l}\text { "treatment with the complementary therapies of CM [Chinese medicine] had to be agreed by the } \\
\text { patients or their families, thus randomly assigning the patients to the ST [standard treatment] or CH } \\
\text { [Chinese herbs] by a completely blind method was difficult" } \\
\text { "there was no fixed CM formula" }\end{array}$ & Lee [27] \\
\hline $\begin{array}{l}\text { Comparison and effect } \\
\text { estimate }\end{array}$ & $\begin{array}{l}\text { "in addition, there is no standard treatment for } \mathrm{AD} \text { [atopic dermatitis] based on evidence-based medicine } \\
\text { that could be used for comparison. Therefore, it is very difficult to rate an intervention compared to a } \\
\text { standard herbal medicine" }\end{array}$ & $\begin{array}{l}\text { Choi } 2012 \\
{[58]}\end{array}$ \\
\hline Blinding & $\begin{array}{l}\text { "although the shape and color of the placebo were similar to Yueju, the smells of Yueju and placebo } \\
\text { were not exactly identical, which may lead to the plausible incomplete blind treatment to patients. }\end{array}$ & Wu [51] \\
\hline Intervention and bias control & $\begin{array}{l}\text { "the current study cannot exclude the possible effects of HAT [herbal acupuncture therapy] on other } \\
\text { factors, such as basic herbal regimens, proper acupuncture selection, and long-term therapeutic courses } \\
\text { involved in the response of IDH [Intradialytic hypotension]" }\end{array}$ & Tsai [47] \\
\hline
\end{tabular}

methodology and reporting in TCM pilot trials, and some issues related to TCM pilot studies still warranted further methodology and guidance. Further endeavors are needed for training and dissemination of guideline adherence, and development of more detailed methodology in the field of TCM pilot trials.

\section{Supplementary information}

Supplementary information accompanies this paper at https://doi.org/10. 1186/s40814-020-00602-4.

Additional file 1: Table S1. Search terms used in the EMBASE, MEDLINE and CNKI.

\section{Acknowledgements}

None

\section{Authors' contributions}

GL, DW, and XC contributed to study conception and design. GL, DW, and $X C$ contributed to searching, screening, data collection, and analyses. GL was responsible for drafting the manuscript. JZ, ZL, and LT provided comments and made several revisions of the manuscript. All authors read and approved the final version.

\section{Funding}

This study was supported by research grant from the Science Foundation of Guangdong Second Provincial General Hospital (YY2018-002) and the Project of State Key Laboratory of Dampness Syndrome of Chinese Medicine (No. 2019KT1209) and Science and Technology Planning Project of Guangdong Province (No. 2017B030314166).

\section{Availability of data and materials}

All the data are already publicly available in the literature.

\section{Ethics approval and consent to participate}

Not applicable.

\section{Consent for publication}

Not applicable.

\section{Competing interests}

The authors declare that they have no competing interests.

\section{Author details}

${ }^{1}$ Center for Clinical Epidemiology and Methodology (CCEM), Guangdong Second Provincial General Hospital, 466 Newport Middle Road, Haizhu District, Guangzhou 510317, Guangdong Province, China. ${ }^{2}$ Department of Health research methods, Evidence, and Impact (HEI), McMaster University, 1280 Main St West, Hamilton, ON L8S 4 L8, Canada. ${ }^{3}$ State Key Laboratory of Dampness Syndrome of Chinese Medicine, The Second Affiliated Hospital of Guangzhou University of Chinese Medicine, Guangzhou, China. ${ }^{4}$ Guangdong Provincial Key Laboratory of Clinical Research on Traditional Chinese Medicine Syndrome, Guangzhou, China.

Received: 23 December 2019 Accepted: 14 April 2020

Published online: 22 April 2020

\section{References}

1. Thabane L, Ma J, Chu R, Cheng J, Ismaila A, Rios LP, Robson R, Thabane M, Giangregorio L, Goldsmith $\mathrm{CH}$. A tutorial on pilot studies: the what, why and how. BMC Med Res Methodol. 2010;10(1):1.

2. Eldridge SM, Lancaster GA, Campbell MJ, Thabane L, Hopewell S, Coleman $\mathrm{CL}$, Bond $\mathrm{CM}$. Defining feasibility and pilot studies in preparation for randomised controlled trials: development of a conceptual framework. PLoS One. 2016;11(3):e0150205.

3. Eldridge SM, Chan CL, Campbell MJ, Bond CM, Hopewell S, Thabane L, Lancaster GA. CONSORT 2010 statement: extension to randomised pilot and feasibility trials. BMJ (Clinical research ed). 2016;355:15239.

4. Shanyinde $M$, Pickering RM, Weatherall M. Questions asked and answered in pilot and feasibility randomized controlled trials. BMC Med Res Methodol. 2011;11(1):117.

5. Avery KN, Williamson PR, Gamble C, O'Connell Francischetto E, Metcalfe C, Davidson P, Williams H, Blazeby JM. Informing efficient randomised controlled trials: exploration of challenges in developing progression criteria for internal pilot studies. BMJ Open. 2017:7(2):e013537.

6. Wilson DT, Walwyn RE, Brown J, Farrin AJ, Brown SR. Statistical challenges in assessing potential efficacy of complex interventions in pilot or feasibility studies. Stat Methods Med Res. 2016;25(3):997-1009.

7. Chen Y-B, Tong X-F. Ren J, Yu C-Q, Cui Y-L: Current research trends in traditional Chinese medicine formula: a bibliometric review from 2000 to 2016. Evid Based Complement Alternat Med. 2019;2019.

8. Horne E, Lancaster GA, Matson R, Cooper A, Ness A, Leary S. Pilot trials in physical activity journals: a review of reporting and editorial policy. Pilot and feasibility studies. 2018;4(1):125.

9. Agarwal S, Jain A, Mourya M, Vandana KC, Jackson P, Choudhary YK. Nastheal, a herbal formula for the treatment of mild asthma: an open, single centric, non-comparative pilot study for 3 weeks. Asian Journal of Pharmaceutical and Clinical Research. 2014;7(4):3-6.

10. Ahn AC, Bennani T, Freeman R, Hamdy O, Kaptchuk TJ. Two styles of acupuncture for treating painful diabetic neuropathy - a pilot randomised control trial. Acupunct Med. 2007;25(1-2):11-7. 
11. Avis NE, Legault C, Coeytaux RR, Pian-Smith M, Shifren JL, Chen W, Valaskatgis P. A randomized, controlled pilot study of acupuncture treatment for menopausal hot flashes. Menopause. 2008;15(6):1070-8.

12. Chen LC, Tsao YT, Yen KY, Chen YF, Chou MH, Lin MF. A pilot study comparing the clinical effects of Jia-Wey Shiau-Yau San, a traditional Chinese herbal prescription, and a continuous combined hormone replacement therapy in postmenopausal women with climacteric symptoms. Maturitas. 2003;44(1):55-62.

13. Chung KF, Yeung WF, Zhang ZJ, Yung KP, Man SC, Lee CP, Lam SK, Leung TW, Leung KY, Ziea ETC, et al. Randomized non-invasive sham-controlled pilot trial of electroacupuncture for postpartum depression. J Affect Disord. 2012;142(1-3):115-21.

14. Gong B, Chen X, Lin R, Zhang F, Zhong J, Zhang Q, Zhou Y, Li H, Zeng L, Jiang $Z$, et al. Safety and efficacy of the C-117 formula for vulnerable carotid artery plaques (Spchim): a randomized double-blind controlled pilot study. Evid Based Complement Alternat Med. 2019;2019:9746492.

15. Hsu CH, Hwang KC, Chao CL, Chang SGN, Ho MS, Lin JG, Chang HH, Kao ST, Chen YM, Chou P. An evaluation of the additive effect of natural herbal medicine on SARS or SARS-like infectious diseases in 2003: a randomized, double-blind, and controlled pilot study. Evid Based Complement Alternat Med. 2008;5(3):355-62.

16. Huang YH, Chen ST, Liu FH, Hsieh SH, Lin CH, Liou MJ, Wang CC, Huang CH, Liu GH, Lin JR, et al. The efficacy and safety of concentrated herbal extract granules, YH1, as an add-on medication in poorly controlled type 2 diabetes: a randomized, double-blind, placebo-controlled pilot trial. PLoS One. 2019;14(8):e0221199.

17. Iwasaki K, Kato S, Monma Y, Niu K, Ohrui T, Okitsu R, Higuchi S, Ozaki S, Kaneko N, Seki T, et al. A pilot study of Banxia Houpu Tang, a traditional Chinese medicine, for reducing pneumonia risk in older adults with dementia. J Am Geriatr Soc. 2007:55(12):2035-40.

18. Jones BM. Changes in cytokine production in healthy subjects practicing Guolin Qigong: a pilot study. BMC Complement Altern Med. 2001;1:8.

19. Kainuma M, Hikiami H, Nozaki K, Hayashi K, Shimada Y, Terasawa K. The effect of a herbal medicine (Mao-to) for the prevention of interferoninduced psychiatric complications in chronic hepatitis C: a pilot study. Human Psychopharmacology. 2004;19(4):235-41.

20. Kalman DS, Feldman S, Feldman R, Schwartz HI, Krieger DR, Garrison R. Effect of a proprietary Magnolia and Phellodendron extract on stress levels in healthy women: a pilot, double-blind, placebo-controlled clinical trial. Nutr J. 2008:7:11

21. Kampman K, Majewska MD, Tourian K, Dackis C, Cornish J, Poole S, O'Brien C. A pilot trial of piracetam and ginkgo biloba for the treatment of cocaine dependence. Addict Behav. 2003;28(3):437-48.

22. Kang LY, Pan XZ, Yang WX, Pan QC, Weng XH, Yang WQ. Chinese herbal formula XQ-9302: pilot study of its clinical and in vitro activity against human immunodeficiency virus. Hong Kong Medical Journal. 1999;5(2):1359.

23. Kong KH, Wee SK, Ng CY, Chua K, Chan KF, Venketasubramanian N, Chen C. A double-blind, placebo-controlled, randomized phase II pilot study to investigate the potential efficacy of the traditional Chinese medicine Neuroaid (MLC 601) in enhancing recovery after stroke (TIERS). Cerebrovasc Dis. 2009;28(5):514-21.

24. Kuo WH, Yao CA, Lin CH, Chang KJ. Safety and efficacy of Tien-Hsien Liquid Practical in patients with refractory metastatic breast cancer: a randomized, double-blind, placebo-controlled, parallel-group, phase lla trial. Evid Based Complement Alternat Med. 2012;2012:803239.

25. Kuratsune H, Umigai N, Takeno R, Kajimoto Y, Nakano T. Effect of crocetin from Gardenia Jasminoides Ellis on sleep: a pilot study. Phytomedicine. 2010;17(11):840-3

26. Ladas EJ, Kroll DJ, Oberlies NH, Cheng B, Ndao DH, Rheingold SR, Kelly KM. A randomized, controlled, double-blind, pilot study of milk thistle for the treatment of hepatotoxicity in childhood acute lymphoblastic leukemia (ALL). Cancer. 2010;116(2):506-13.

27. Lee HC, Hsieh CL, Chen CC, Cho DY, Cheng KF, Lin PH. A pilot study in acute subarachnoid haemorrhagic patients after aneurysm clipping with complementary therapies of Chinese medicine. Complementary therapies in medicine. 2010;18(5):191-8..

28. Lee HW, Lim MS, Seong SJ, Park J, Lee J, Seo JJ, Kim SD, Shin HM, Yoon YR. Clinical evaluation of efficacy and tolerability of HMCO5 in healthy subjects with normal and high-normal blood pressure: a pilot study. Planta Med. 2011;77(3):221-5.
29. Li GY, Yu XM, Zhang HW, Zhang B, Wang CB, Xin YC, Yang CZ, Zhou RX, Wang LX. Haishengsu as an adjunct therapy to conventional chemotherapy in patients with non-small cell lung cancer: a pilot randomized and placebo-controlled clinical trial. Complementary therapies in medicine. 2009; 17(1):51-5.

30. Li T, Xie J, Routy JP, Li Y, Han Y, Qiu Z, Lv W, Song X, Sun M, Zhang X, et al. Tripterygium wilfordii hook $\mathrm{f}$ extract in CART-treated hiv patients with poor immune response: a pilot study to assess its immunomodulatory effects and safety. HIV Clinical Trials. 2015;16(2):49-56.

31. Liew WK, Loh W, Chiang WC, Goh A, Chay OM, Kidon MI. Pilot study of the use of Yin Qiao San in children with conventional antipyretic hypersensitivity. Asia Pacific Allergy. 2015;5(4):222-9.

32. Liu J, Li Z, Liu H, Wang X, Lv C, Wang R, Zhang D, Du X, Li Y, Wang B, et al. Metabolomics-based clinical efficacy and effect on the endogenous metabolites of Tangzhiqing tablet, a Chinese patent medicine for type 2 diabetes mellitus with hypertriglyceridemia. Evid Based Complement Alternat Med. 2018:2018:5490491.

33. Luo YN, Zhou YM, Zhong X, Zhao L, Zheng QH, Zheng H, Tang L, Jia PL, Wu Q, Huang $C$, et al. Observation of pain-sensitive points in patients with knee osteoarthritis: a pilot study. European Journal of Integrative Medicine. 2018; 21:77-81.

34. Noorbala AA, Akhondzadeh S, Tahmacebi-Pour N, Jamshidi AH. Hydroalcoholic extract of Crocus sativus L. versus fluoxetine in the treatment of mild to moderate depression: a double-blind, randomized pilot trial. 」 Ethnopharmacol. 2005;97(2):281-4.

35. Otto KC, Quinn C, Sung YF. Auricular acupuncture as an adjunctive treatment for cocaine addiction: a pilot study. Am J Addict. 1998;7(2):16470.

36. Pan XW, Zhang XG, Chen XC, Lu Q, Hu YS, Han LY, Zheng JL, Jin J, Zheng GQ. A survey of application of complementary and alternative medicine in Chinese patients with Parkinson's disease: a pilot study. Chinese Journal of Integrative Medicine. 2018:1-6.

37. Reshef A, Bloch B, Vadas L, Ravid S, Kremer I, Haimov I. The effects of acupuncture treatment on sleep quality and on emotional measures among individuals living with schizophrenia: a pilot study. Sleep Disorders. 2013;327820.

38. Ritenbaugh C, Hammerschlag R, Calabrese C, Mist S, Aickin M, Sutherland E, Leben J, DeBar L, Elder C, Dworkin SF. A pilot whole systems clinical trial of traditional Chinese medicine and naturopathic medicine for the treatment of temporomandibular disorders. J Altern Complement Med. 2008;14(5): 475-87.

39. Scheid V, Tuffrey V, Weijburg T, Bovey M, Ward T. Chinese medicine treatment for menopausal symptoms in the UK health service: is a clinical trial warranted? Maturitas. 2015;80(2):179-86.

40. Shelmadine BD, Bowden RG, Moreillon JJ, Cooke MB, Yang P, Deike E, Griggs JO, Wilson RL: A pilot study to examine the effects of an antiinflammatory supplement on eicosanoid derivatives in patients with chronic kidney disease. Journal of alternative and complementary medicine (New York, NY) 2017, 23(8):632-6638.

41. Singh RG, Rathore SS, Kumar R. Usha, Agarwal A, Dubey GP: Nephroprotective role of salacia chinensis in diabetic CKD patients: a pilot study. Indian J Med Sci. 2010;64(8):378-84.

42. Sitzia C, Meregalli M, Belicchi M, Farini A, Arosio M, Bestetti D, Villa C, Valenti $L$, Brambilla P, Torrente Y: Preliminary evidences of safety and efficacy of flavonoids- And omega 3-based compound for muscular dystrophies treatment: a randomized double-blind placebo controlled pilot clinical trial. Front Neurol 2019, 10(JUL):755.

43. Sordi R, Castro SN, Lera AT, Irene MN, Farinazzo MM, Sette C, Cubero DIG, Baccarin ALC, Del Giglio A. Randomized, double-blind, placebo-controlled phase ii clinical trial on the use of uncaria tomentosa (Cat's claw) for aromatase inhibitor-induced arthralgia: a pilot study. Journal of Natural Remedies. 2019:19(1):24-31.

44. Spasov AA, Wikman GK, Mandrikov VB, Mironova IA, Neumoin W. A doubleblind, placebo-controlled pilot study of the stimulating and adaptogenic effect of Rhodiola rosea SHR-5 extract on the fatigue of students caused by stress during an examination period with a repeated low-dose regimen. Phytomedicine. 2000;7(2):85-9..

45. Stockert K, Schneider B, Porenta G, Rath R, Nissel H, Eichler I. Laser acupuncture and probiotics in school age children with asthma: a randomized, placebo-controlled pilot study of therapy guided by principles of Traditional Chinese Medicine. Pediatr Allergy Immunol. 2007;18(2):160-6. 
46. Tao F, Lu H, Basdevant A, Oppert JM. Obesity phenotypes: a pilot study on the traditional Chinese medicine approach. Obes Facts. 2013;6(SUPPL. 1):63-4.

47. Tsai M-Y, Wu C-H, Huang Y-C, Chen S-Y, Ng H-Y, Su Y-J, Chen Y-H. Treatment of intradialytic hypotension with an herbal acupoint therapy in hemodialysis patients: a randomized pilot study. Complementary therapies in medicine. 2018:38:67-73.

48. Wang J, Tsoh JY, Burke A, Le GM, Stewart S, Wong C, Chow E, Fung LC, Woo KJ, Nguyen TT. A pilot study using traditional chinese medicine providers to promote colorectal cancer screening in the Chinese American community. J Altern Complement Med. 2014;20(5):A106-7.

49. Wei D, Lv C, Zhang J, Peng D, Hu L, Zhang Z, Wang Y. The therapeutic effect of xueshuan xinmai tablets on memory injury and brain activity in post-stroke patients: a pilot placebo controlled fMRI study. Int J Clin Exp Med. 2015;8(5):7507-16.

50. Wong VCN, Sun JG, Yeung DWC. Pilot study of efficacy of tongue and body acupuncture in children with visual impairment. J Child Neurol. 2006;21(6): 462-73.

51. Wu R, Zhu D, Xia Y, Wang H, Tao W, Xue W, Xia B, Ren L, Zhou X, Li G, et al. A role of Yueju in fast-onset antidepressant action on major depressive disorder and serum BDNF expression: a randomly double-blind, fluoxetineadjunct, placebo-controlled, pilot clinical study. Neuropsychiatr Dis Treat. 2015:11:2013-21.

52. Xu G, Zhao W, Zhou Z, Zhang R, Zhu W, Liu X. Danshen extracts decrease blood $C$ reactive protein and prevent ischemic stroke recurrence: a controlled pilot study. Phytother Res. 2009;23(12):1721-5.

53. Yu X. Salmoni A: comparison of the prophylactic effect between acupuncture and acupressure on menstrual migraine: results of a Pilot Study. JAMS Journal of Acupuncture and Meridian Studies. 2018;11(5):303-14.

54. Zhang J, Xu K, Wei D, Guo R, Li H, Wang Y, Zhang Z. The effects of Bushen capsule on episodic memory in amnestic mild cognitive impairment patients: a pilot placebo controlled fMRI study. Journal of Alzheimer's disease : JAD. 2015;46(3):665-76.

55. Zou P, Dennis $C L$, Lee R, Parry M: Hypertension prevalence, health service utilization, and participant satisfaction: findings from a pilot randomized controlled trial in aged Chinese Canadians. Inquiry : a journal of medical care organization, provision and financing 2017, 54:46958017724942.

56. Zou P, Dennis $C L$, Lee R, Parry M. Dietary approach to stop hypertension with sodium reduction for Chinese Canadians (Dashna-CC): a pilot randomized controlled trial. J Nutr Health Aging. 2017;21(10):1225-32.

57. Wu L, Shi S. Clinical value and feasibility of acupuncture and massage in the treatment of degenerative knee arthritis. Linchuang Yiyao Wenxian Dianzi Zazhi 2014,1(07):1199-1201 [Article in Chinese].

58. Choi IH, Kim S, Kim Y, Yun Y. The effect of TJ-15 plus TJ-17 on atopic dermatitis: a pilot study based on the principle of pattern identification. Journal of alternative and complementary medicine (New York, NY). 2012; 18(6):576-82.

59. Arain M, Campbell MJ, Cooper CL, Lancaster GA. What is a pilot or feasibility study? A review of current practice and editorial policy. BMC Med Res Methodol. 2010;10:67.

60. Chan CL, Leyrat C, Eldridge SM. Quality of reporting of pilot and feasibility cluster randomised trials: a systematic review. BMJ Open. 2017;7(11): e016970.

61. Sim J. Should treatment effects be estimated in pilot and feasibility studies? Pilot Feasibility Stud. 2019;5:107.

62. MacPherson $\mathrm{H}$, Altman DG, Hammerschlag R, Youping L, Taixiang W, White A, Moher D. Revised STandards for Reporting Interventions in Clinical Trials of Acupuncture (STRICTA): extending the CONSORT statement. PLoS Med. 2010;7(6):e1000261.

63. Gagnier JJ, Boon H, Rochon P, Moher D, Barnes J, Bombardier C. Recommendations for reporting randomized controlled trials of herbal interventions: explanation and elaboration. J Clin Epidemiol. 2006;59(11): 1134-49.

64. Stoll CRT, Izadi S, Fowler S, Green P. The value of a second reviewer for study selection in systematic reviews; 2019.

\section{Publisher's Note}

Springer Nature remains neutral with regard to jurisdictional claims in published maps and institutional affiliations.

\section{Ready to submit your research? Choose BMC and benefit from}

- fast, convenient online submission

- thorough peer review by experienced researchers in your field

- rapid publication on acceptance

- support for research data, including large and complex data types

- gold Open Access which fosters wider collaboration and increased citations

- maximum visibility for your research: over $100 \mathrm{M}$ website views per year

At $\mathrm{BMC}$, research is always in progress.

Learn more biomedcentral.com/submissions 